\title{
Erratum to: Education of non-medical practitioners in Germany-an analysis of course subjects of specialized schools
}

\author{
Lea Hoffmeister (iD · Karsten Muenstedt · Jutta Huebner · Christian Keinki
}

(c) The Author(s), under exclusive licence to Springer-Verlag GmbH Austria, ein Teil von Springer Nature 2022

\section{Erratum to:}

Wien Med Wochenschr 2021

https://doi.org/10.1007/s10354-021-00896-w

The correct order of authors is Lea Hoffmeister, Karsten Münstedt, Jutta Hübner, Christian Keinki.

Jutta Hübner and Christian Keinki contributed equally.

Publisher's Note Springer Nature remains neutral with regard to jurisdictional claims in published maps and institutional affiliations.

The online version of the original article can be found under https://doi.org/10.1007/s10354-021-00896-w.

\section{Hoffmeister $\cdot$ K. Muenstedt}

Department of Gynecology and Obstetrics, Ortenauklinikum

Offenburg, Ebertplatz 12, 77654 Offenburg, Germany

J. Huebner $(\bowtie) \cdot$ C. Keinki

Department of Internal Medicine, University Hospital Jena,

Am Klinikum 1, 07747 Jena, Germany

Jutta.Huebner@med.uni-jena.de 